\title{
New macroeconomics teaching for a new era: instability, inequality, and environment
}

\author{
Jonathan M. Harris \\ Global Development and Environment Institute, Tufts University, Medford, MA, USA
}

\begin{abstract}
The financial crisis of 2008 and its aftermath offer an opportunity to institute significant reform in economics teaching, starting at the introductory level. Mainstream macroeconomics texts still rely heavily on a classical assumption of a long-run full employment equilibrium, which underrates the possibility, severity, and duration of economic crises. They have little treatment of inequality, virtually no consideration of its macroeconomic effects, and pay almost no attention to the environment. A better approach starts with the use of a dynamic AS/AD model, with inflation rather than the price level on the vertical axis, avoiding the spurious implication that there is some stable price level at which the entire macroeconomy will reach equilibrium. With this approach, there is no presumption that the economy will automatically return to a situation of full employment. Rather, there is an important role for conscious fiscal and monetary policy. In this context, it becomes possible to discuss how economies can be characterized by different equilibria and disequilibria, varied growth paths with different environmental impacts, and inherent instability. The analysis can be used to illustrate recent and historical shifts in the economy and economic policy responses. While not necessarily tied to the concept of a 'green economy,' a more dynamic analysis is strongly compatible with an environmental interpretation of macroeconomics, including environmental policy to respond to global climate change and other problems.
\end{abstract}

Keywords: macroeconomics, financial crisis, inequality, environment, pedagogy

JEL codes: E00, E12, E60, E62, E63, Q50, Q57, Q58

We are now 7 years past the financial crisis of 2008, but we are still dealing with its aftereffects. Slow recovery in the US and the threat of global slowdown and renewed recession in Europe indicate that we are living in a new era, which some have characterized as secular stagnation or even depression. The economics profession has not covered itself with glory either in its failure to anticipate the crisis or in its response to the new situation (Madrick 2014). While there has been some effort to adapt theoretical perspectives and some grudging acceptance of the kinds of policies that, prior to the crisis, would have been regarded as outdated Keynesianism, there has been little real change either in mainstream economic theories or in standard economics texts. This poses a problem for instructors in economics. How can economics teaching reflect current realities in a way that will be both instructive and interesting to students?

I and my colleagues at the Tufts University Global Development and Environment Institute view this dilemma as an opportunity to institute significant reform in economics teaching, starting at the introductory level. The second edition of our text, Macroeconomics in Context (Goodwin et al. 2014), gives extensive attention to the origins and outcome of the financial crisis, and also attempts to introduce a revised theoretical framework that is better suited to understanding issues of inequality, instability, and environment.

Most mainstream macroeconomics texts generally lack treatment of these key issues. They still rely heavily on a classical assumption of a long-run full employment 
equilibrium, which underrates the possibility, severity, and duration of economic crises. They have little treatment of inequality, and virtually no consideration of its macroeconomic effects. In most cases the word 'environment' does not even appear in the index, or receives the briefest of treatments, being relegated to a purely microeconomic analysis, and a narrowly defined one at that. The importance of social investment and investment in infrastructure gets very limited attention. This is all related to a misleading, and theoretically inaccurate, version of Aggregate Supply/Aggregate Demand analysis.

The AS/AD analysis found in almost all introductory texts uses the price level on the vertical axis. This requires various assumptions about sticky wages and prices and money illusion to construct a short-term AS curve with a positive slope. Lacking these assumptions, the model reduces to a vertical 'long-run aggregate supply curve' that absolutely determines the level of economic equilibrium. Changes in demand, including government fiscal and monetary policy, are only capable of affecting the price level in the long run.

In addition to this inherent classical bias, the model is, as David Colander has pointed out, theoretically inconsistent. The appearance of an independent AS and AD curve is an illusion; the $\mathrm{AD}$ curve is not really an aggregate demand curve but rather a curve showing a collection of $\mathrm{AS} / \mathrm{AD}$ equilibrium points, each of which would properly be associated with a different AS curve. The model seems to 'work,' and at least in the 'short-term' version may appeal to students as it appears to be simply a revised version of a microeconomic supply/demand analysis. But the principles of macroeconomic equilibrium are not those of microeconomic price equilibrium: the macroeconomic adjustment process does not work only through price adjustment, and the process itself is likely to shift the curves, meaning that their typical textbook application as comparative statics is invalid. The appearance of a price-mediated equilibrium between a single $\mathrm{AD}$ curve and a single $\mathrm{AS}$ curve is thus theoretically unacceptable, but convenient for what Colander/Sephton (1998) has called 'dirty pedagogy' presenting a seemingly simple model of the macro economy.

One solution to this problem would be to abandon AS/AD entirely - but this would be unlikely to work, given the dominance of AS/AD in textbooks. An alternative approach, which we have used in our text (Goodwin et al. 2014), is to present a dynamic AS/AD model with inflation rather than the price level on the vertical axis. The advantage of this is that it avoids the spurious implication that there is some stable price level at which the entire macroeconomy will reach equilibrium. Rather, different output levels are associated with different levels of inflation. Our model starts from the reality that inflationary pressures increase as the economy approaches maximum capacity, giving an AS curve that is essentially a reversed Phillips curve. Its position can be affected by positive or negative supply shocks or changing inflationary expectations (Figure 1). The macroeconomic equilibrium is reached by a process of adjustment of aggregate demand and inflation levels, and there is no equilibrating function based on the overall price level. The AS as we have drawn it also has a flat section based on the possibility of a liquidity trap. ${ }^{1}$

The AD curve is derived from an underlying Keynesian model, but acquires its slope from a combination of real wealth, interest rate, and trade effects, and an assumed central bank reaction function to inflation. It can be shifted by autonomous changes in consumption or investment, or by fiscal and monetary policy.

The many factors that can lead to shifts in either of the curves create a model that reflects real economic instabilities. There is no presumption that the economy will

1. One weakness of our presentation is that it does not show the possibility of deflation. This could be added, though, by changing inflationary expectations such that the entire curve shifts downward in very recessionary conditions. 


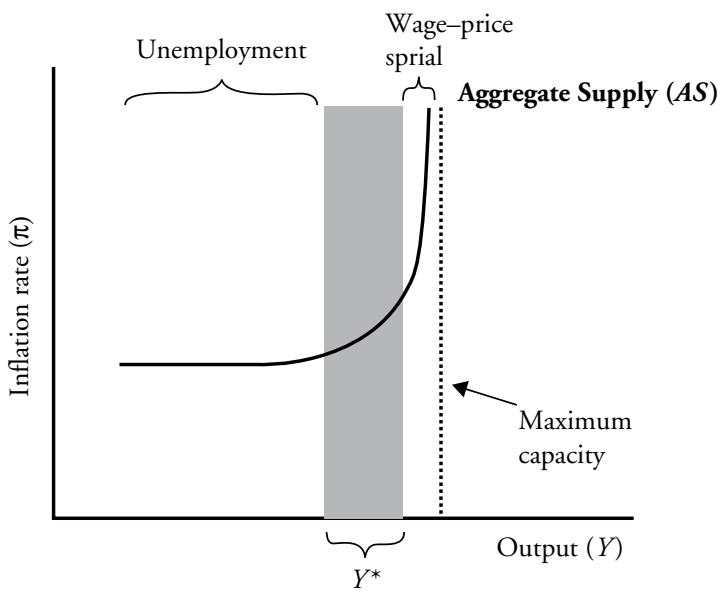

Note: As the economy approaches its maximum capacity, inflation levels tend to rise as excessive demand for workers, goods and services, and production inputs pushes up wages and prices. Source: Goodwin et al. (2014: ch. 13).

\section{Figure 1 The Aggregate Supply curve}

automatically return to a situation of full employment. Rather, there is an important role for conscious fiscal and monetary policy. In particular, in a situation of depressed aggregate demand, activist policy is essential to return to full employment (shown in this model as a range rather than a single level, based on the reality that there is no unambiguous definition of 'full employment'). An expansionary government policy in response to a recession is shown by a rightward shift in the $\mathrm{AD}$ curve (Figure 2).

The interactions of the curves are easily graspable by introductory students, but they do not rely on a theoretically inaccurate analogy to microeconomic supply/demand analysis. This non-classical framework also provides a much better basis for analysis of issues of inequality and environment.

In this context, it becomes possible to discuss how economies can be characterized by different equilibria and disequilibria, varied growth paths, and inherent instability. ${ }^{2}$ The analysis can be used to illustrate recent and historical shifts in the economy and economic policy responses. Some simple dynamics resulting from changing inflationary expectations can easily be added when discussing, for example, the effects of tight money policies in the 1980 s, technological innovation in the 1990s, or the danger of a deflationary trap in recent times.

This approach somewhat resembles but in important respects differs from the kind of dynamic AS/AD model presented at a more advanced level by Mankiw (2010) in his intermediate Macroeconomics text. The underlying assumptions used in our textbook (Goodwin et al. 2014) are different, placing less emphasis on 'natural level of output' and more on stochastic shocks and policy intervention. There is also no assumption that falling inflation can restore full-employment equilibrium, especially in conditions of a liquidity trap and possible deflation. The model does not include any Minskyan analysis of financial instability or other possible causes of economic crisis, although it refers to 'investor and consumer confidence and expectations' (Goodwin et al. 2014: 298). But it

2. See Colander/Kupers (2014: ch. 6, 'How macroeconomics lost the complexity vision'). 


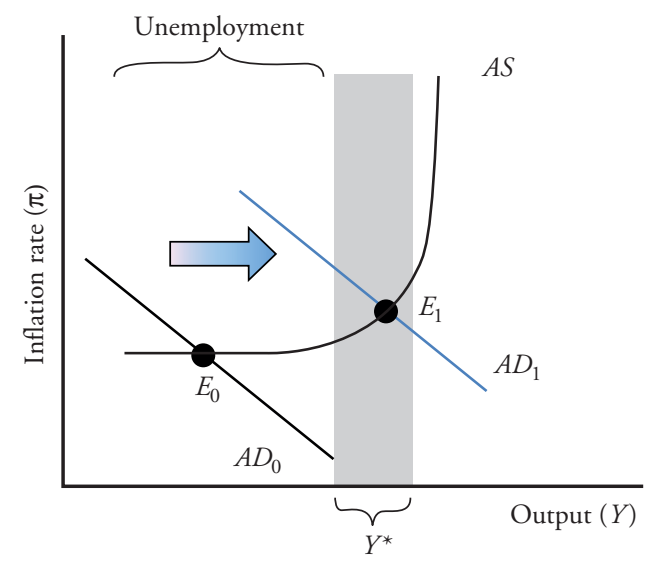

Note: An expansion of government spending, as well as a program of tax cuts, shifts the $A D$ curve to the right.

Source: Goodwin et al. (2014: ch. 13).

Figure 2 Expansionary fiscal policy in response to a recession

is followed by a full chapter on the origins of the 2007-2008 financial crisis, with comparisons of the Great Recession and the Great Depression (Goodwin et al. 2014: 343-362, ch. 15 'The Financial Crisis and the Great Recession'). This represents an essentially Keynesian perspective, in contrast to the general classical bias in mainstream models, even those that are presented at a more sophisticated level. The Keynesian model provides a good backdrop to the empirical explanation of major economic instability and policy responses.

This analysis is not simply a traditional Keynesian view, though. It can easily be adapted to address twenty-first century problems of environment and inequality. For example, in dealing with climate change (a topic that is generally absent from macroeconomics texts), it is important to note that many different growth paths for the economy exist, some high-carbon and some low-carbon. It is also crucial to see how government policy can make an essential difference in determining which path the economy follows. The Goodwin et al. (2014: 413-441) chapter on 'Growth and sustainability' emphasizes the opportunities for low-carbon pathways, and also explores the possibilities for 'green Keynesian' policies of environmental investment, and the long-term possibility of economic growth adapting to a steady-state economy.

In this perspective, the issue of inequality is also clearly important to macroeconomic policy and outcomes. If we are in a classical world where the economy is headed back to full-employment equilibrium of its own accord, there is no special reason to be concerned about inequality - which accounts for its absence from most texts in macroeconomics. But in a Keynesian perspective, the distribution of income is both an important feature of macro policy and an important determinant of macro outcomes, given the greater marginal propensity to consume of people at lower income levels. A stable middle class is a crucial foundation for a stable macroeconomy, and the kind of dramatically increasing inequality seen recently, as was seen also in the 1920s and 1930s, is a major contributing factor to instability and potential economic collapse. The Goodwin et al. (2014) introductory text does not delve into Kaleckian modeling of income distribution, but does describe in a more empirical fashion the importance of income distribution and the effects of 
inequality on economic development. This should prepare students who go to more advanced levels to understand the importance of including income distribution in macro models.

This non-classical analysis is also not wedded to an assumption of indefinite economic growth as a 'natural' and inevitable path. Different measures than GDP may be consistent with improved well-being (as both Simon Kuznets, the father of GDP accounting, and Keynes himself acknowledged). There is also no inherent reason why GDP and population should not stabilize at some level, as shown in Peter Victor's economic models of the Canadian economy (Victor 2008). Such stabilization, if it is to take place without high unemployment, requires assumptions regarding equity and environmental policies, such as shorter work weeks and the use of carbon taxes. But there is nothing in the economic analysis presented here that renders this impossible or ties the health of the economy to indefinite economic growth.

While it is not necessarily tied to the concept of a 'green economy,' a more Keynesian and dynamic analysis is strongly compatible with an environmental interpretation of macroeconomics. Chapters 6 and 18 of the Goodwin et al. (2014) text, for example, include concepts of revised national income accounts, 'green Keynesian' policies ${ }^{3}$ using social and environmental investment to promote full employment, 'green' taxes including carbon tax, and the possibility of limits to growth and a steady-state economy (a concept with a fine intellectual pedigree going back to John Stuart Mill, ${ }^{4}$ and recently and somewhat surprisingly endorsed by growth theorist Robert Solow ${ }^{5}$ ).

Breaking away from the price-mediated equilibrium of standard AS/AD takes us out of a classical, Walrasian world in which government fiscal and monetary policy is essentially ineffective or damaging. We enter instead the real world of the twenty-first century, in which issues of instability, stagnation, inequality, and environmental crisis dominate the picture and cry out for an intellectually sound guide to activist policy responses. These can include fiscal, monetary, and regulatory policy aimed at promoting employment and reducing economic instability. They can also include aggressive environmental policy to respond to global climate change and other problems. Analysis of these issues goes well beyond the basic AS/AD model, but using a dynamic model prepares students to think about these real-world problems rather than remaining trapped in a 'self-equilibrating' classical economics world.

Examples of successful activist policy are not hard to find. The Obama administration stimulus program instituted in response to the 2007-2009 recession included \$71 billion for specifically 'green' investments, plus $\$ 20$ billion in 'green' tax incentives. The overall stimulus package was judged by macroeconomists Alan Blinder and Mark Zandi (2010: 1) to have 'probably averted what could have been called Great Depression 2.0 ... without the government's response, GDP in 2010 would be about $11.5 \%$ lower, payroll employment would be less by some $8^{1 / 2}$ million jobs, and the nation would be experiencing deflation.'

3. See Harris (2013).

4. See book IV, chapter 6 of Mill's Principles of Political Economy, on the Stationary State (Mill 1848 [1994]).

5. 'There is no reason at all why capitalism could not survive with slow or even no growth. I think it's perfectly possible that economic growth cannot go on at its current rate forever ... it is possible that the US and Europe will find that ... either continued growth will be too destructive to the environment and they are too dependent on scarce natural resources, or that they would rather use increasing productivity in the form of leisure ... There is nothing intrinsic in the system that says it cannot exist happily in a stationary state' (Robert Solow, quoted in Stoll 2008: 2). 
Prior to the European financial crisis, Portugal implemented a government-led transition from fossil fuels towards renewable power, with the percentage of renewable supply in Portugal's grid up from 17 percent in 2005 to 45 percent in 2010, based on a $\$ 22$ billion investment in modernizing electrical grid and developing wind and hydropower facilities. This was facilitated by European Union carbon credits, and led to savings of about $\$ 2.3$ billion a year in avoided natural gas imports (Rosenthal 2010). Of course, such programs are now considered out of the question in the age of European austerity. But why? What would be the problem with a massive investment to solarize Southern Europe, putting many unemployed people back to work and avoiding fossil fuel import costs forever?

Standard economic analysis tells us that such a program would be unwise because it would increase deficits and debt and risk inflation. But, as Paul Krugman (2011) has pointed out, 'suppose that government uses borrowed money to buy useful things like infrastructure. The true social cost will be very low, because the spending will put resources that would otherwise be unemployed to work [and allow private debtors to pay down their debt] ... the argument that debt can't cure debt is just wrong.' Europe's problems now arise from unwillingness to use the European Central Bank to finance debt, allowing indebted players to recover. Instead, 'austerity' policies make debt harder to manage and threaten major defaults and financial catastrophe. Similarly, the US focus on debt reduction prevents further stimulus spending, threatening to derail a weak recovery. 'Until the private sector demand recovers, more expansionary domestic policies are needed - not just in Europe, but globally' (Temin/Vines 2014: 106).

A 'greener' economic view implies policies such as increased public sector hiring, increased public R\&D expenditures, and investment in public transit and infrastructure, public health, education, and environmental conservation and regeneration. Specific climaterelated policies could include a carbon tax or equivalent, energy efficiency and renewables investment, strong efficiency standards for vehicles and power plants, and infrastructure for public transit and high-speed rail. All of these promote both employment and climate stability, and can be justified by rigorous economic analysis. While textbooks should not prescribe specific policies, they should make it clear to students that a much wider range of activist fiscal, monetary, and regulatory policies exist than are implied by the narrow, New Classical-biased models that dominate existing texts.

\section{REFERENCES}

Blinder, A.S., Zandi, M. (2010): How the Great Recession was brought to an end, URL: http://www.economy.com/mark-zandi/documents/End-of-Great-Recession.pdf.

Colander, D., Kupers, R. (2014): Complexity and the Art of Public Policy, Princeton, NJ: Princeton University Press.

Colander, D., Sephton, P. (1998): Acceptable and unacceptable dirty pedagogy: the case of AD/AS, in: Bhaskara Rao, B. (ed.), Aggregate Demand and Supply: A Critique of Orthodox Macroeconomic Modelling, New York: St. Martin's Press, 137-154.

Goodwin, N., Harris, J.M., Nelson, J.A., Roach, B., Torras, M. (2014): Macroeconomics in Context, 2nd edn, Armonk, NY and London: M.E. Sharpe.

Harris, J.M. (2013): Green Keynesianism: beyond standard growth paradigms, in: Richardson, R.B. (ed.), Building a Green Economy: Perspectives from Ecological Economics, East Lansing, MI: Michigan State University Press, 69-82.

Krugman, P. (2011): Mr. Keynes and the moderns, Paper presented at Cambridge UK conference commemorating the 75th anniversary of the publication of The General Theory of Employment, Interest, and Money. 
242 European Journal of Economics and Economic Policies: Intervention, Vol. 12 No. 2

Madrick, J. (2014): Seven Bad Ideas: How Mainstream Economists have Damaged America and the World, New York: Alfred A. Knopf.

Mankiw, N.G. (2010): Macroeconomics, 7th edn, New York: Worth.

Mill, J.S. (1848 [1994]): Principles of Political Economy: and Chapters on Socialism, edited and with an introduction by Jonathan Riley, Oxford and New York: Oxford University Press.

Rosenthal, E. (2010): Portugal gives itself a clean energy makeover, in: The New York Times, 10 August.

Stoll, S. (2008): Fear of fallowing: the specter of a no-growth world, in: Harper's Magazine, March, URL: http://harpers.org/archive/2008/03/fear-of-fallowing/.

Temin, P., Vines, D. (2014): Keynes: Useful Economics for the World Economy, Cambridge, MA: MIT Press.

Victor, P. (2008): Managing without Growth: Slower by Design, not Disaster, Cheltenham, UK and Northampton, MA: Edward Elgar. 